〔講演 : プロテオーム解析による生命活動の解明〕

\author{
ゲノム情報とプロテオーム情報の統合によってもたらされる \\ 生命情報科学の新展開
}

\title{
戸田年 総
}

\begin{abstract}
SUMMARY
After completion of the Human Genome Project, the main target of the next research has shifted to elucidation of functions of unidentified novel genes. In this situation, expectation for the contribution of proteomic research to the bioinformatics has been getting heavier. The unification of genome database and proteome database may promote an advancement of post-genome researches. All spots of proteins isolated on a 2-D gel pattern can be easily assigned to their own sequence on a chromosome by tblastn search served by NCBI. After the mapping of all 2-D gel spot to genomic DNA, the function of unidentified genes will be thoroughly inquired by proteomic research. Many techniques in proteomics can offer much information about tissue/cell specific expression of the gene products, functional regulation by differentiation and carcinogenesis, intracellular localization, protein-to-protein interaction, and posttranslational modifications. A lot of information gathered by proteomic research may help us to assign a specific function to each protein corresponding to its unidentified gene.
\end{abstract}

Key words : bioinformatics, proteomics, genomics, postgenome.

\section{はじめに}

ヒトゲノムDNAの全塩基配列解読計画が発表されたと き，誰しもが無謀な計画だと思ったに違いない。それがな んと 2001 年の 2 月には, 国際コンソーシアムのグルー プ1) とセレラ・ジェノミックスのグループ2) によってそれ ぞれ独立に解読結果が報告され, 事実上の目標達成宣言が 出されてしまった。実際には多数のギャップで分断された ドラフト（概要配列）に過ぎず，完全解読は 2003 年頃に なるが，すでにいくつかのことが明らかになった。なかで も特筆すべきことは，これまで約 10 万と推定されていた ヒトの遺伝子総数が $3 \sim 4$ 万に下方修正されたことである. 国際コンソーシアムグループが約 31,778 , セレラ・ジェ ノミックスグループが 26,383〜39,114 という数字を出し ており, 理化学研究所のグループも約 36,500 と推定して いることから，これはほぼ確実であろう。ヒトが八エや線
虫の遺伝子の 2 倍程度しか持たないというのは驚きである が，この推定值にはオルターナティブスプライシングの数 は含まないので, 蛋白質の総数は, やはり当初推定されて いた 10 万にかなり近い值になるものとみられる.さらに, 予測された遺伝子のうち約 $60 \%$ が機能未知の新規遺伝子 であったということも注目に值する。今回みつかった新規 遺伝子の機能解明に扔けるプロテオーム研究の果たすべき 役割は大きい

\section{ポストゲノム時代の研究戦略}

ヒトゲノム DNA の解析によって，蛋白質をコードする 領域であるとされた配列の中に，機能が未知の遺伝子が多 数みつかったことから，今後はこれらの遺伝子の機能（正 しくは遺伝子がコードする蛋白質の機能）を解明する研究 に軸足が移される．蛋白質の機能を推定する方法の一つ は,コンピュータを用いてモチーフ構造や立体構造を予測

Prospective advancement in bioinformatics generated by unification of genome database and proteome database.

Tosifusa Toda ; 東京都老人総合研究所遺伝子情報部門プロテオーム共同研究センター

Corresponding address : Tosifusa Toda, Department of Gene Regulation and Protein Function, Tokyo Metropolitan Institute of Gerontology, 35-2, Sakae-cho, Itabashi-ku, Tokyo 173-0015, Japan.

第 51 回日本電気泳動学会総会・特別講演 
し，既知の蛋白質の中から類似性の高いものを探し出すこ とである.しかしこれはあくまでも遺伝子の予測そのもの が正しいという前提に立った上でのことであり，オル夕ー ナティブスプライシングの影響や翻訳後修飾の影響は加味 されないなどの問題がある.もう一つは，プロテオーム研 究の技法を駆使するものである.詳細は後で述べるが, 最 初に，できるだけ分解能の高い分離法を用いて蛋白質を網 羅的に分離し，酵素消化ペプチドのマススペクトルやアミ ノ酸配列情報を手がかりに，ゲノム DNA のドラフト配列 セグメント上へのマッピングを行う。その上で, 発生や分 化, 癌化, 種々の疾患における発現動態の変化, 細胞内局 在, 他分子との相互作用, 翻訳後修飾の状態などを蛋白質 レベルで詳しく調べ，機能を明らかにしょうというもので ある。

\section{プロテオーム研究の方法論}

プロテオーム研究が，これまでの古典的な蛋白質研究と 異なる点は網羅性にある。ゲノム DNAの全塩基配列を完 全に読みつくすことを目標としたゲノム計画の後を受け， 新規遺伝子の機能を解明することを目指して実施される蛋 白質研究の柱としてプロテオーム研究が注目を集めている 最大の理由はここにある. 蛋白質分析の網羅性を実現する ためには，少なくとも次の 3 つ要素が満たされなければ ならない. 第 1 は広範な等電点/分子量領域をカバーでき る広いダイナミックレンジを有し，わずかな等電点/分子 量の違いであっても分離できる高い分解能を有する蛋白質 分離法が利用できること, 第 2 は極めて微量の蛋白質をも 検出できる高感度の蛋白質検出法が利用できること, 第 3 は単離された全ての蛋白質に対し，既知の場合には同定 を，未知の場合にはゲノム DNA上へのマッピングができ るハイスループットの構造解析・データベース検索法が利 用できることである. 現在, プロテオーム研究で主流とな っている IPG-DALT 二次元電気泳動 ${ }^{3)}$ (一次元目に固定 化 $\mathrm{pH}$ 勾配ゲル等電点電気泳動を, 2 次元目に濃度勾配ゲ ルもしくはトリスートリシン緩衝液を用いた SDS-PAGE を実施する二次元電気泳動）と質量分析を組み合わせた方 法は，現時点においてこれらの条件にもっとも近いもので あり，一定の制限の範囲内では十分に成果が期待できるも のである．残念ながら，現状ではまだ分離できない蛋白質 や検出されない蛋白質が残されていることも事実である が，これについては，今後さらに改良を重ねることによっ て解決できるものと考える. 二次元電気泳動法に比べると 分解能は多少落ちるが, キャピラリー電気泳動や親和電気 泳動, 二次元 $\mathrm{HPLC}^{4)}$ なども, 将来有望な蛋白質分離法 である。また，多段の質量分析法（MS/MS）の一段目を 蛋白質の分離法として利用することもできる．検出法につ いては, 銀染色なみに高感度でありながら, クマシー染色
なみに定量性が高いサイプロルビーを用いる方法5) が今後 は主流になっていくものと思われる。

\section{蛋白質の同定におけるゲノム研究情報の役割}

蛋白質の同定を行うとき，これまではプロテインシーク エンサーを用いて $\mathrm{N}$ 末端の部分や内部ペプチドのアミノ 酸配列を読み，データベース検索を行う方法が一般的であ ったが, より微量化, 高速化が要求されるプロテオーム研 究では，質量分析による同定が主流になっている．質量分 析で得られる情報は, 試料中にどのような分子質量 (molecular mass) のペプチドがどのような量比で存在し ているかを示すマススペクトルである.したがって，純粋 に単離された蛋白質をトリプシンなどで消化し, 質量分析 を行うと，その蛋白質のいわゆるぺプチドマスフィンガー プリント（マスマップともいう）が得られる．質量分析で 求められた分子質量の数值は, 安定同位元素（たとえば ${ }^{12} \mathrm{C}$ と $\left.{ }^{13} \mathrm{C}\right)$ の比率の違いも見分けられるほど精度が高く, すでにデータベースに登録されている既知の蛋白質の場合 には，ペプチドマスフィンガープリントだけで蛋白質を同 定することができる。この方法で同定ができなかった場合 には未知の蛋白質である可能性が高いが, 消化が不十分で あることも考えられるので，念のためにアミノ酸配列分析 を行い，再度データベース検索を試みる，このとき，イン ターネット上の検索ソフトとデータベースを利用してオン ラインで行う方法と, データベースを丸ごとダウンロード し，手元のソフトを用いてオフラインで検索を行う方法と がある、インターネット上で利用できる検索サイトとして は, UCSF の ProteinProspector (http://prospector. ucsf.edu/) やSIB の ExPASy Proteomics tools (http:// www.expasy.ch/tools/）などがある. ProteinProspector にアクセスしてペプチドマスフィンガープリンティングを 行う場合, MS-FITという検索ソフトを利用することに なるが，検索の対象となるデータベースとしては， SWISS-PROT などの蛋白質データベースだけでなく， NCBInrのような「DNA 塩基配列の翻訳によって作られ た推定蛋白質配列データベース」を利用することもでき る。

対象が既知の蛋白質（少なくとも cDNAレベルではク ローン化されているもの）であった場合，上記の方法で同 定ができるはずであるが，いろいろパラメータを変えて検 索を行っても相同性の高いものがみつからなかった場合, 新規の蛋白質である可能性が高い. 分析サンプルがヒト由 来のもの，あるいはヒトとの相同性が高い動物由来のもの の場合, NCBI が提供する「ヒトゲノム DNA データベー スの tblastn 検索」（Fig. 1）を利用して，ゲノム DNA 上 へのマッピングを行う。この場合，入力するアミノ酸配列 が 21 残基以上ないとうまく検索できないので，できるだ 


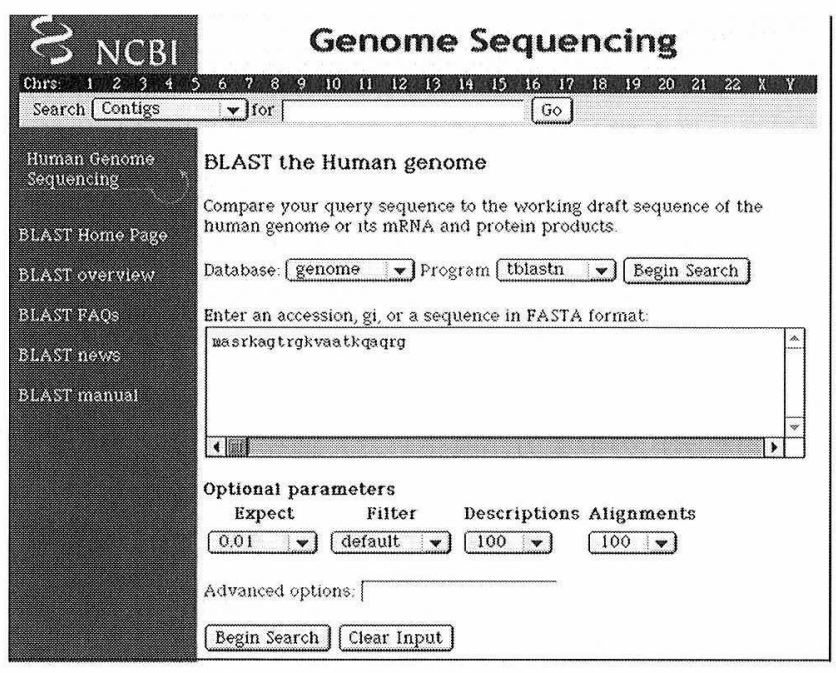

Fig. 1. NCBI Human Genome BLAST Search Query.

The URL of the query home page is http://www.ncbi.nlm.nih. gov/BLAST/.

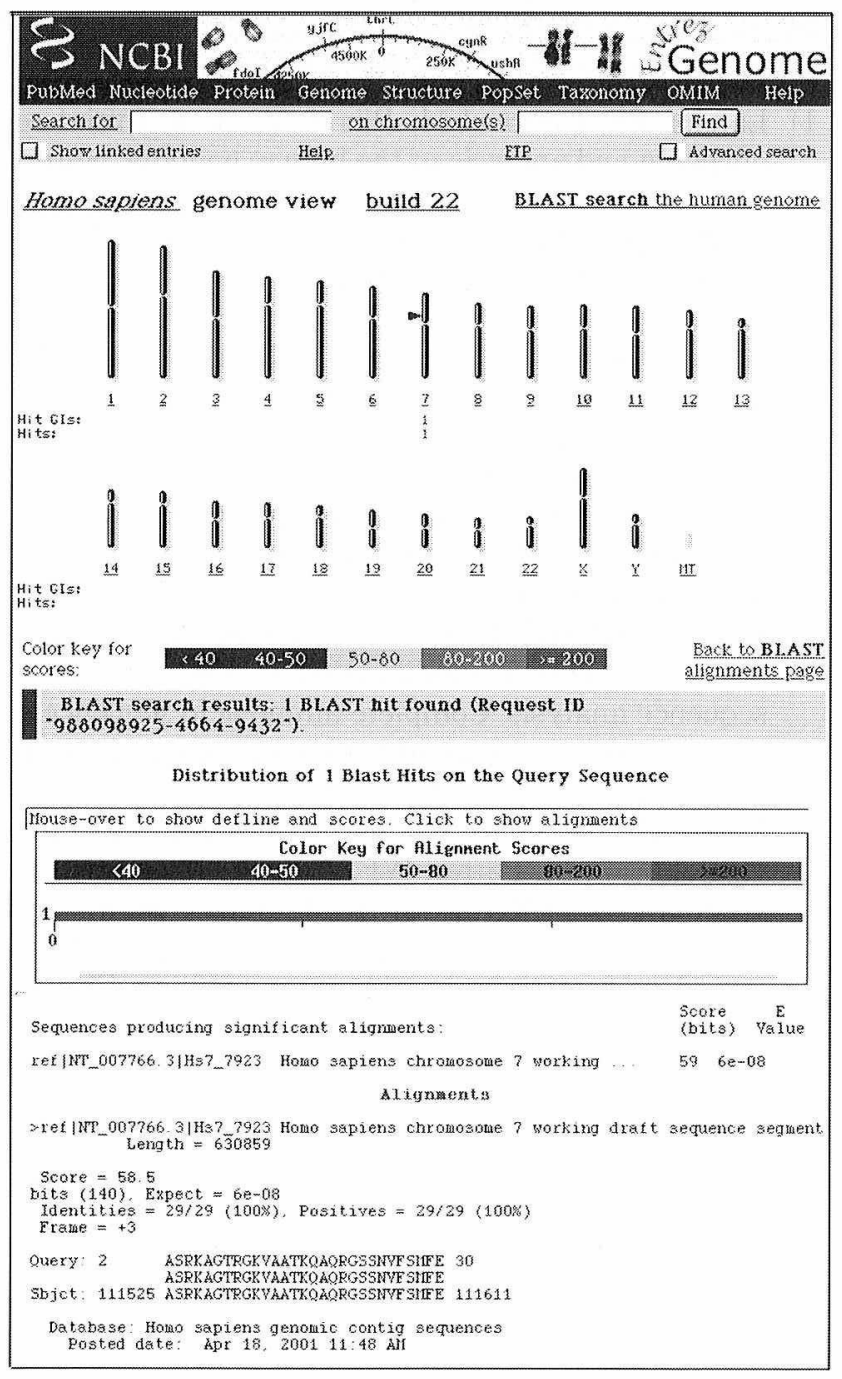

Fig. 2. NCBI Human Genome BLAST Search Result.

The results is obtained by the tblastn search program on human genome database with the query sequence "masrkagtrgkvaatk qaqre".
け長く配列を読んで㧍く必要がある. 残念ながら質量分析 による配列分析で 20 残基以上読むことは事実上不可能で あるので，この場合には，やはり従来のエドマン法による シークエンシングを行う。Fig. 2 に例として，ヒトのミオ シン軽鎖 $2 \mathrm{a}$ の配列を 21 残基入力して検索を行った結果 を示した。この配列部分は第 7 染色体由来の working draft sequence segment (630,859 塩基長) の 111,525 塩 基目からのストレッチに帰属し，ここ以外に同じ配列をコ ードする遺伝子は存在しないことが，このゲノムDNAの 検索によってわかる。

\section{プロテオーム研究によって得られる情報}

新規遺伝子の塩基配列領域にマッピングされた蛋白質に ついて, 現在プロテオーム研究で得ることのできる情報 は，おおよそ次のようなものである。

1. 組織別, 部位別, 細胞別にみたときの発現量の違い 組織別, 部位別, 細胞別に調製した抽出液を二次元電気 泳動し，画像解析によって定量的な比較を行う。

\section{2. プロセッシングや翻訳後修飾の有無}

二次元電気泳動で得られた蛋白質スポットの $\mathrm{N}$ 末端配 列や分子質量を分析し，ゲノムDNAの構造から推定され る前駆体蛋白質の配列や質量と比較する。また等電点や分 子量が異なる副スポットの有無を確認する。また, 修飾構 造を特異的に認識する抗体が利用できるものについては, ウェスタンブロットによって確認する。修飾構造の特定は 質量分析（MS/MS 法）によって行う。

\section{3. 細胞内局在性}

蔗糖密度勾配超遠心法などで細胞内の小器官を分別採取 し, それぞれの蛋白質を二次元電気泳動/画像解析法で比 較分析する。

4. 細胞分化や癌化に伴う変動, 刺激に対するレスポン ス

細胞の分化誘導前後, 癌化前後, 刺激を加える前後の細 胞から蛋白質を抽出し, 二次元電気泳動/画像解析法で比 較分析寸る。

\section{5. 複合体の形成や蛋白質相互作用}

複合体を壊さない条件で蛋白質を抽出し，マイルドな条 件で複合体のまま蛋白質を分画し，そこに含まれる蛋白質 を二次元電気泳動/質量分析で分離同定する。また，親和 電気泳動や，表面反応/プラズモン共鳴センサー6) を用い て，相互作用の有無を検出することもできる。

\section{6. 特定の疾患に伴う変化}

特定の疾患の患者検体より蛋白質を抽出し, 二次元電気 泳動/画像解析法で健常者の対象検体と比較分析する。

$$
\text { ゲノム情報とプロテオーム情報の統合 }
$$

現在，米国の NCBI と欧州の EMBL，および我が国の 
国立遺伝研の連携によって維持管理されているDNA デー タベースは，主にクローニングによって得られた cDNA の塩基配列，および，ゲノムライブラリーから読み出され たゲノム DNA の配列が主情報であるが, 副情報として蛋 白質に翻訳された時のアミノ酸配列情報や，報告されてい る翻訳産物の機能, 細胞内局在, 疾患等との関連, および これらの文献情報なども付随しており，SWISS-PROTな どの蛋白質一次構造データベース, PDB などの立体構造 データベースへのリンクも張られている。一方, 蛋白質一 次構造データベースの主情報は, 精製された蛋白質の分析 によって得られたアミノ酸配列情報であるが，こちら側に も, 細胞内局在や報告されている機能, 疾患との関わり, 文献情報などが盛り込まれており，ゲノムデータベースへ のリンクも張られている。この両者は, 主情報は異なるも のの副情報には共通の項目が多く, 互いに表裏一体の関係 になっている.これに対し, 二次元電気泳動パターンの上 に画像解析や質量分析によって得られた情報を乗せていく 形のプロテオームデータベースは, 配列情報を主情報とす るデータベースとは全く異質なものである.そもそもプロ テオームデータベースは，異なる動物種や細胞種の情報を 一つにまとめることができないので, 二次元電気泳動パ夕 ーンごとに数多くのデータベースを作らなければならない という制約があるが，その反面，従来のデータベースには なかった定量的な情報や動的な情報が盛り込まれることが プロテオームデータベースの最大の特長である.したがっ て，プロテオームデータベース上で同定された蛋白質スポ ットをDNA データベースや蛋白質データベースに相互リ ンクすることは，互いに欠けている情報を補完することに なり，情報の利用価值を飛躍的に向上させる.

\section{情報の統合によって生まれる新しい生命科学}

ヒトを含めた全ての動物個体の生命活動は個体を構成す る細胞の機能によって支えられているが，個々の細胞の機 能は蛋白質の機能に基づいており，その蛋白質の構造と機 能はDNA にコードされている，このため，全ての生命現 象の根底にゲノム情報があることは確かであり，ゲノム情 報を解読することが生命現象を理解する上で重要であるこ とは間違いない.しかしゲノム情報が蛋白質に翻訳され， 翻訳後修飾を受け，互いに複合体を形成する段階に至る と, 塩基配列情報からは予想できない高次の機能を獲得す る. 細胞や個体の生命活動を正しく理解するためには，ゲ ノム情報に加え蛋白質レベルの研究によって得られる情報
が不可欠である。

これまでの生命科学研究は, 基礎と臨床, 細胞と個体, 遺伝子と蛋白質など, 領域やカテゴリーごとに行われてき たが, 研究が進み, 非常に多くの情報が蓄積された結果, 相互に情報を交換することによって, あるいは情報を関連 づけて一つにまとめることで, 個別の研究では得られなか った総合的な生命現象の理解が可能になってきている。こ のような状況を背景に，バイオインフォーマティクス（生 命情報科学）の考え方が誕生した。情報の中身については これから議論されていくものと思われるが，少なくとも分 子レベルでは「ゲノム情報」「トランスクリプトーム情報」 「プロテオーム情報」が入り，さらに「細胞情報」「組織情 報」「臨床医学情報」など, 幅広い領域の情報が一元的に 扱える方向に進むものと思われる。そのためにも, 各領域 の研究で得られた情報は全て電子化し，データベース化し て，インターネット上で共有することができるIT 環境を 今から整えておく必要がある。

\section{文 献}

1) Lander ES, Linton LM, Birren B, et al. Initial sequencing and analysis of the human genome. Nature 2001 ; 409 : 860-921.

2) Venter JC, Adams MD, Myers EW, et al. The sequence of the human genome. Science $2001 ; 291$ : 1304-51.

3) Gorg A, Boguth G, Obermaier C, Posch A, Weiss W. Two-dimensional polyacrylamide gel electrophoresis with immobilized $\mathrm{pH}$ gradients in the first dimension (IPG-Dalt): The state of the art and the controversy of vertical versus horizontal systems. Electrophoresis 1995 ; 16 : 1079-86.

4) Takahashi N, Takahashi Y, Putnam FW. Twodimensional high-performance liquid chromatography and chemical modification in the strategy of sequence analysis. Complete amino acid sequence of the lambda light chain of human immunoglobulin D. J Chromatogr 1983 ; 266 : 511-22.

5) Lopez MF, Berggren K, Chernokalskaya E, Lazarev A, Robinson M, Patton WF. A comparison of silver stain and SYPRO Ruby Protein Gel Stain with respect to protein detection in two-dimensional gels and identification by peptide mass profiling. Electrophoresis $2000 ; 21$ : 3673-83.

6) Natsume $T$, Nakayama $H$, Jansson $O$, Isobe $T$, Takio K, Mikoshiba K. Combination of biomolecular interaction analysis and mass spectrometric amino acid sequencing. Anal Chem 2000; 72 : 4193-8. 